NB

1270

P3C6X

CHM Ref.

SMITHSONIAN

LIBRARIES 


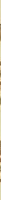

S $\mid$ I $\forall \forall$ प्व 17 LIBRARIES

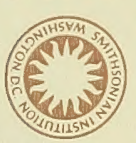

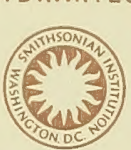

NOIINLILSNI

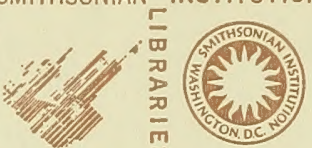

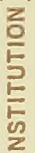

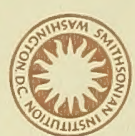

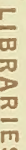

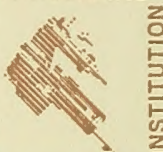

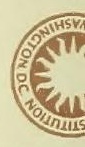

NSTITL
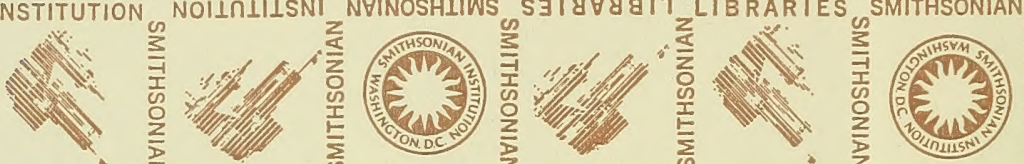

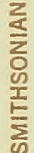
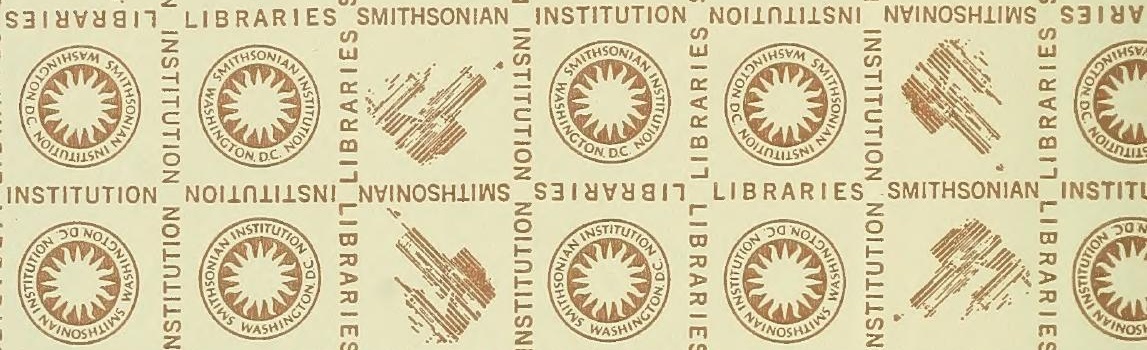

INSTITL
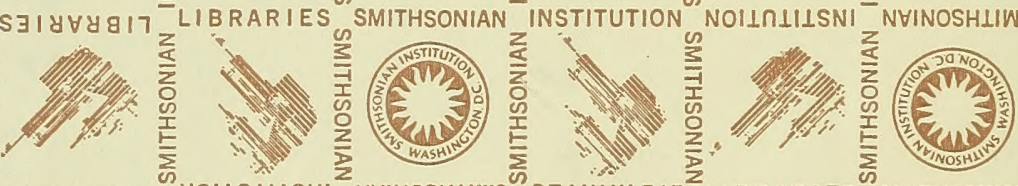

$e^{2}$
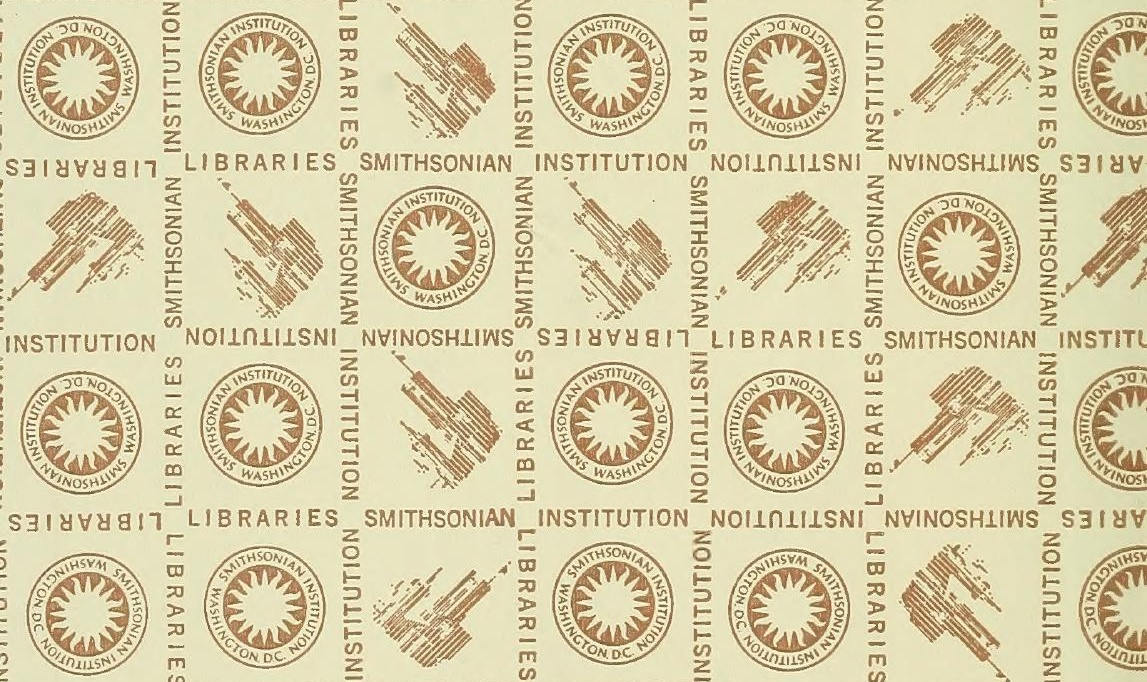

INSTITUTION

NOILIIISNI
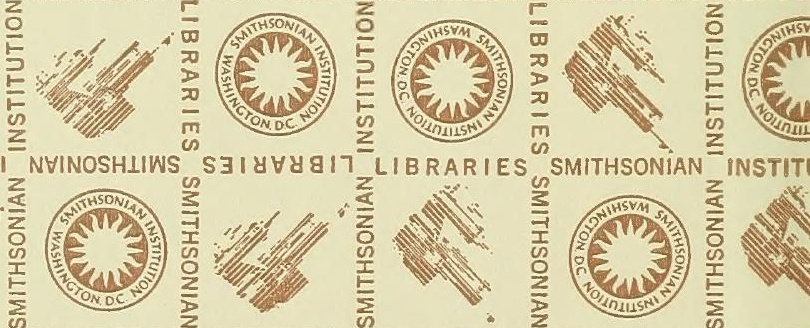

INSTITI

,

उI $\forall \forall \forall 817^{2}$ LIBRARIES SMITHSONIAN

年 

PLANE GEOM ATTY > FANCY AsSURE

An Exhibition of the Art X. Technique of Paper Folding. 



\section{PLANE GEOMETRY AND}

\section{FANCY FIGURES}

THE ART AND TECHNIQUE OF PAPER FOLDING

THE COOPER UNION MUSEUM FOR THE ARTS OF DECORATION 


\title{
ACKNOWLEDGMENT
}

In assembling material for the exhibition, the Museum has received most helpful suggestions and information from the following, to whom are given very grateful thanks:

\author{
Professor Mary F. Blade \\ Miss Louise Crane \\ RAYMOND B. DOWDEN \\ Miss Victoria Kent \\ Gershon Legman \\ Mrs. Harry C. Oppenheimer \\ Francis William PaAr \\ Miss Maria de Unamuno
}




\section{INTRODUCTION}

A man discovered that among its almost unimaginable variety of uses, paper could be folded. With this discovery, paper became something more than a merely useful commodity, a means of recording the literary and artistic ideas and historical acts of man, it became itself a vehicle for artistic expression. Out of paper could be created three-dimensional images or images that gave an illusion of three-dimensional form, depending as much on the technical skill and aesthetic sense of the artist as on the particular kind of paper used and its material characteristics.

As with so many of the western world's civilized refinements, paper and its use has come to us from the Orient, for while papyrus served the ancient Egyptians, Greeks and Romans as a form of paper for both writing and illustration, paper as we regard it today was the invention of the Chinese during the Eastern Han dynasty (25-220 A.D.). In the middle of the 8 th century, a Chinese attack on the Arabs in Samarkand resulted in the initial introduction of paper and the knowledge of its manufacture into the Arab world. In Europe, the manufacture of paper was first established by the Moors in Spain during the 12 th century.

In spite of its early adoption in Europe and the quick adaptation of its manufacture to European natural substances, paper itself has never assumed in the Occident quite the same degree of symbolic meaning nor have objects made of paper been used in the same ceremonial way as in the Orient. Among the Chinese, paper houses, paper servants, paper chests filled with paper money are all elaborately constructed and burned in funeral rites so they may assume reality in the hereafter and assist the deceased to live in the manner of his life on earth, and paper mock money enclosed in red paper envelopes is burned at weddings to assure future happiness. ${ }^{1}$

In Japan, paper carps are hoisted in the air and carried about on 'Boys' Day,' a festival held on the fifth day of the fifth month of the year, and carefully folded paper ornaments are attached to gifts that are ceremonially exchanged on various occasions such as weddings, birthdays, anniversaries and New Year's Day. The Japanese have an intrinsic regard for paper that has almost no parallel in the western world, a regard apparent in the quantity of laboriously hand-manufactured papers of rare quality that are produced in Japan. As with paper, paper folding has an older traceable history in the 
Far East than in the western world, and it may be assumed that like paper itself an initial introduction into Europe of the art of paper folding came from the Orient, perhaps by way of the same Arab invaders who first established paper manufacture on European soil.

In the middle ages, both Oriental and European papers, the latter's manufacture based on that of the former, were distinguished by a firm, stout substance; and in the laws of King Alphonso X of Spain (1252-1284) paper is referred to as cloth parchment. ${ }^{2}$ Cloth folding is known to have existed since the time of the ancient Egyptians, ${ }^{3}$ and while stiffly folded cloth may have been a part of the elaborate hierarchical costume of the early medieval Byzantine court, ${ }^{4}$ it apparently was not popularly used in western Europe until the late middle ages. Following the general elaboration of European dress, which in itself shows strong influences of the Byzantine East, folded cloth appears as part of regular dress and was an especially favored device for ladies' headdresses in the late $15^{\text {th }}$ and early 16 th centuries, ${ }^{5}$ a device still used for the headdresses of some nurses and for certain orders of nuns, such as the impressive starched white linen caps worn by the Sisters of Charity of St. Vincent de Paul. ${ }^{6}$

The creation of three-dimensional objects in folded cloth, distinct from folds as part of clothing, became an established part of table settings for banquets in the 16 th and 17 th centuries. The setting for a banquet given by the late 16 th century Pope, Gregory XIII, "in honor of twenty cardinals and three ambassadors" comprised "a table ... decorated with wonderfully folded napkins. Also the centerpiece - a castle - was made of napkins." 7

Whether the creation of animals, birds and flowers from starched cloth led naturally to the creation of the same popular subjects in the sister medium of paper, at a time when cloth and certain types of paper still had like physical characteristics, or whether in the European development the two arts were independent of each other, with paper folding more directly descendant from an earlier practice of the art in the Orient, is a yet unsolved question.

In the Codex Atlanticus, that monument to the scientific mind of Leonardo da Vinci, are found a number of geometric exercises that clearly make use of folding as simple visual illustration, with one in particular a near duplicate to the typical folded paper aeroplane of today. ${ }^{8}$ In some instances, the text contains the word "falcata," meaning 'bent' or 'folded,' and while there is no mention of material of any kind, it is not difficult to imagine Leonardo would have found paper a more tractable medium than cloth. Modern geometry resorts to paper folding especially in dealing with the three-dimensional problems in the XI Book of Euclid to demonstrate the geometric construction of regular polygons and circles, ${ }^{9}$ and its use in experimenting with engineering principles and with architectural forms and spatial dispositions, the 
relationships between solids and voids, may be seen by leafing through any number of today's many magazines devoted to engineering and architecture. ${ }^{10}$

For architects and designers trained in the Bauhaus tradition, paper folding is fundamental. Moholy-Nagy, one of the teachers at the famous school in Dessau, wrote: "Another type of exercise ... is the manipulation of flat sheets (of paper) into three-dimensional structures. This provides the basic methodology for approaching any flat sheet or slab, such as cardboard, plywood, metal, wire mesh, and plastic, ... manipulations (introductory to) not only inventiveness but also to such basic engineering principles as strength of materials, stress and strain, tension and compression." 11

While the Bauhaus and its influence are usually associated with architecture and the fine arts, its effect on commercial design has been enormous. As a direct or indirect result of Bauhaus ideas, designers of packaging for commercial products, of various types of advertising layouts, of countless objects for the home such as lampshades and even ashtrays, are more and more realizing the many uses to which folded paper can be put, not merely as a method in preliminary design experiments but as finished, highly useful and decorative objects in themselves.

As an art unrelated to geometry, engineering or architectural design principles, paper folding exists in its most developed form in Japan. Called 'origami' in Japanese, paper folding is at once an art that apparently shares equal rank with the more familiar arts of painting and sculpture (and consequently an art whose practitioners reach their highest expression in the unique individualism of each created object) and is an art complexly linked with the stylized traditions of the Japanese. Among the popular subjects of the origami artist are such traditional figures as the crane and tortoise, both symbols of good fortune and longevity of life, the carp, symbolic of persistency and aspiration, and the frog, an emblem of love and fertility. In addition to such symbolic figures, the origami artist creates all sorts of three-dimensional animals, birds and fish, the best of which are works of art of extraordinary quality, with the paper itself, selected with infinite care, becoming an inherently expressive part of the particular object's form.

Japanese are careful to distinguish between paper folding, paper cutting and paper constructions held together with a glue, an approach that indicates that the finished object is judged as much by the way in which it is made as by its completed effect. It is a form of discipline that suggests an ultimate connection with or derivation from Zen, that aspect of Buddhism first introduced into Japan towards the end of the 12th century. In succeeding centuries, the mystical character of Zen had a pronounced effect on Japanese religious life and was a dominant influence on the Japanese samurai, or warrior class. The teaching of Zen stressed the identification of the soul with 
the universe, and aimed at establishing an intimate relationship between man and the life rhythm of nature. ${ }^{12}$ Zen was, and is, a way of life, and its emphasis on discipline of the self applied as much to the artist as to the warrior, his aesthetic vision as well as the physical process of creativity.

Apart from origami as an art in the sense of the individually unique, folded paper has a role in the ceremonial etiquette of Japanese life, as used for the paper decorations attached to gifts, which, however, include many of the traditional figures of origami such as the crane and tortoise. Unlike origami, these decorations are designed purely as traditional emblems, the proper decoration on the proper gift to be given on the proper occasion. Whether the paper is folded into a recognizable form or an abstract shape, the folded object is termed 'noshi,' and the noshi is always attached to the gift with a bound paper string culminating in a sometimes elaborately tied knot called 'mizuhiki.' 13 Frequently, a wisp of seaweed is enclosed in the fold symbolizing the sea separating Japan and the mainland from which the Mongolian Japanese originally came. A further connection with the sea exists in the derivation of the noshi itself. In medieval Japan of the 12 th century it was customary for warriors going into or returning from battle to eat, ceremonially, the dried meat of abalone, and the meat was regarded as ritualistically suitable for exchange as a gift. In time, the meat of abalone became symbolized by the paper noshi and, in fact, one of the meanings of the word noshi is 'dried sea-ear' or the meat of the sea creature known as abalone.

Books with diagrams and instructions for folding the traditional paper decorations were published as early as the first quarter of the 18 th century, a fact indicating a long established tradition. ${ }^{14}$ Characteristic of Japanese forms of etiquette is adherence to ceremony prescribed by tradition. In the

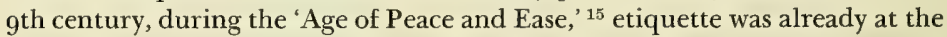
heart of Japanese civilization, and in the $14^{\text {th }}$ century under the influence of Zen the rules of etiquette were systematized by the ruler, Yoshimitsu. ${ }^{16}$ The tea ceremony was among the principal rites formalized, and it may be imagined that included also in the systematization were the proper usages to be followed in the exchange of gifts, the correct emblems for appended paper folds, and proper methods for their folding. Elusive though they are, these traces of paper folding point to a very long history in Japan, especially in respect to the 'gift' folds, and it is reasonable to guess that origami as an art may have an equally long history.

No such history, or widespread popularity for the art, is evident among Europeans and, even today, paper folding in the western world enjoys the general status of a craft and hobby rather than a fine art, with creative amusement and diversion rather than artistic expression the usually accepted criteria. In particular instances, however, original paper folds have been 

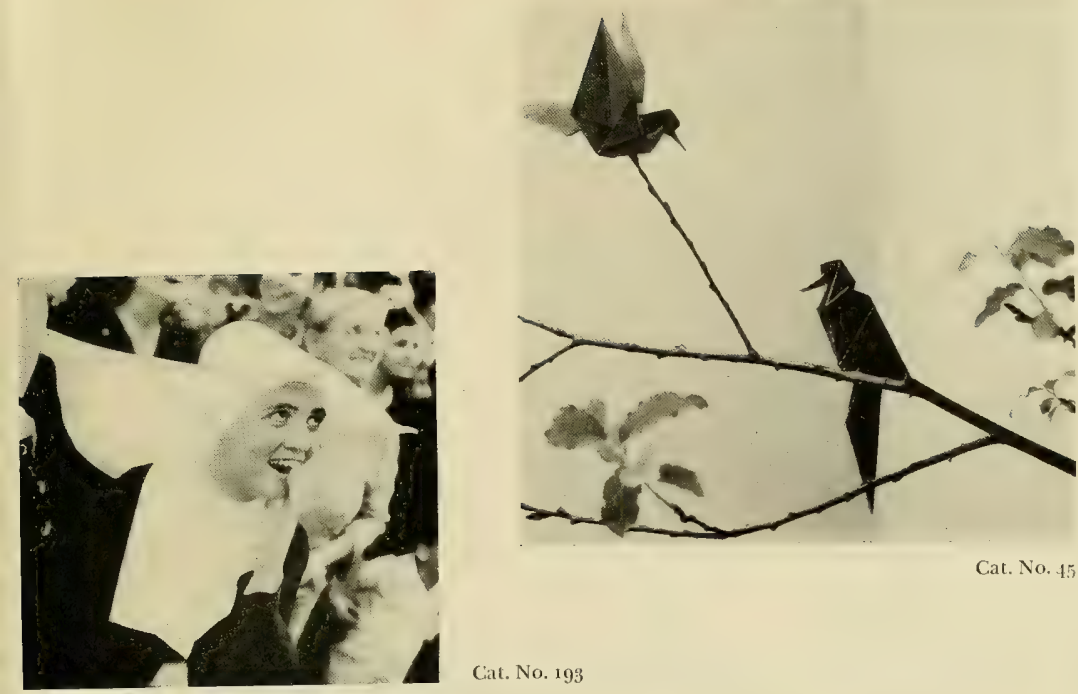

Cat. No. 45

Cat. No. 193

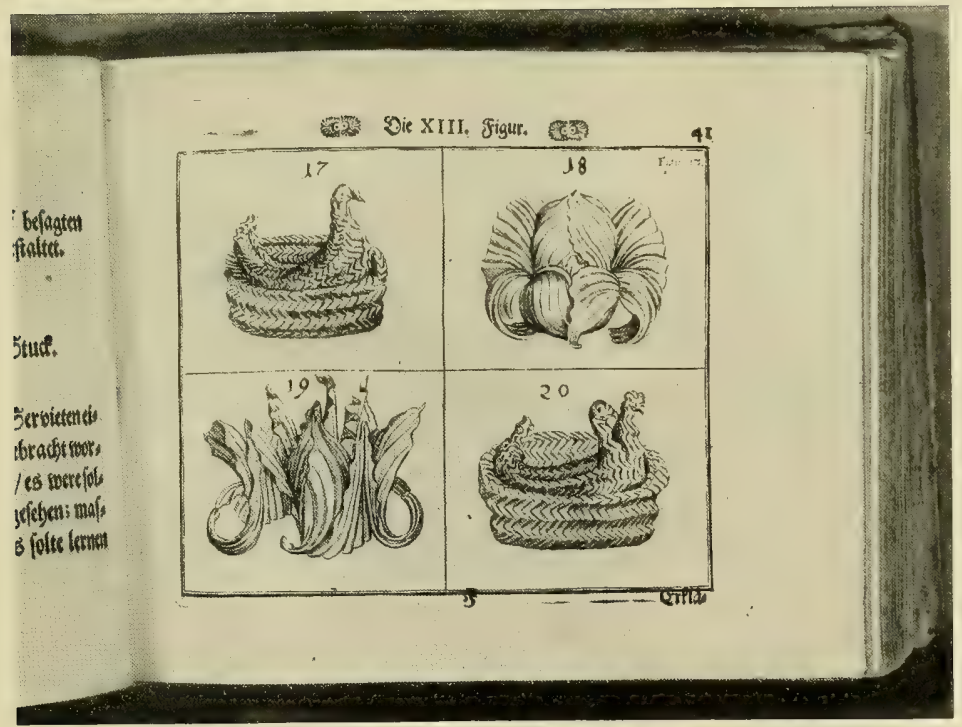

Cat. No. 184 


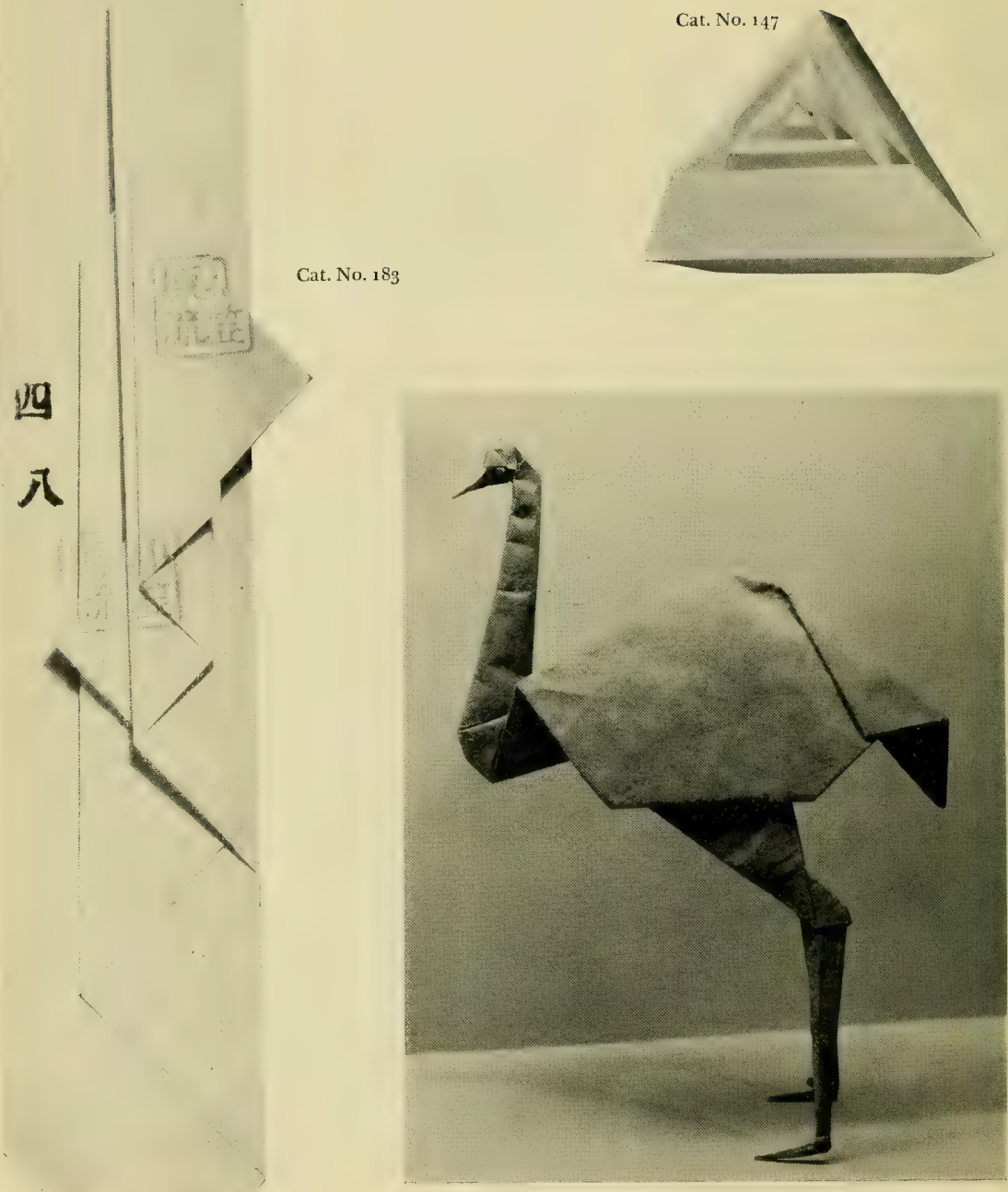


Cat. No. 192

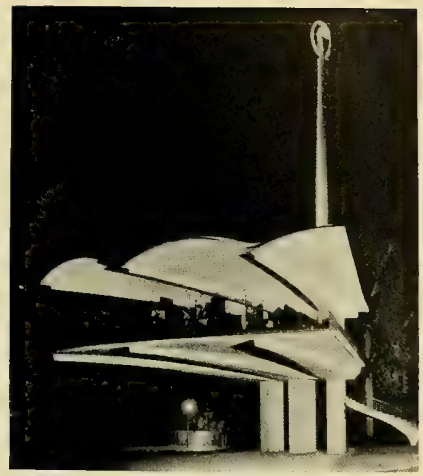

Cat. No. 173
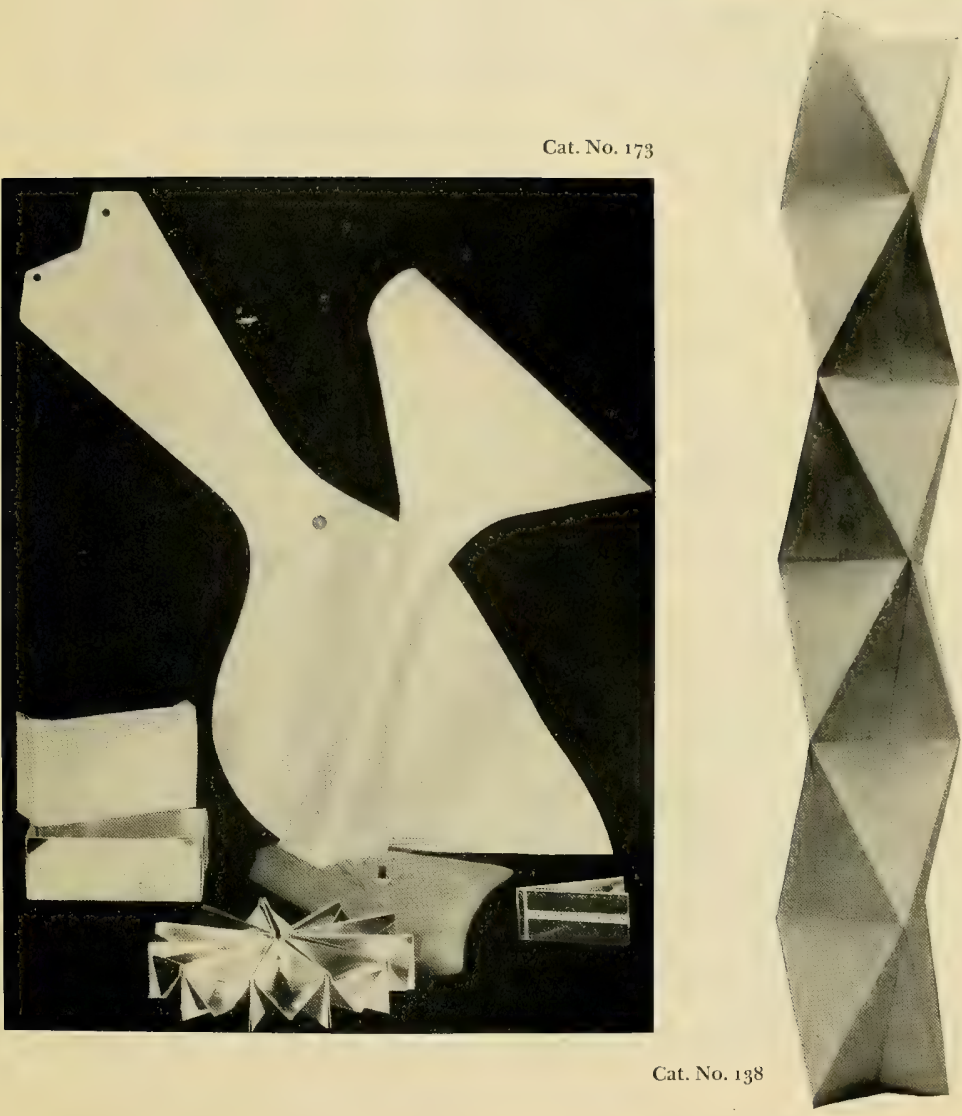


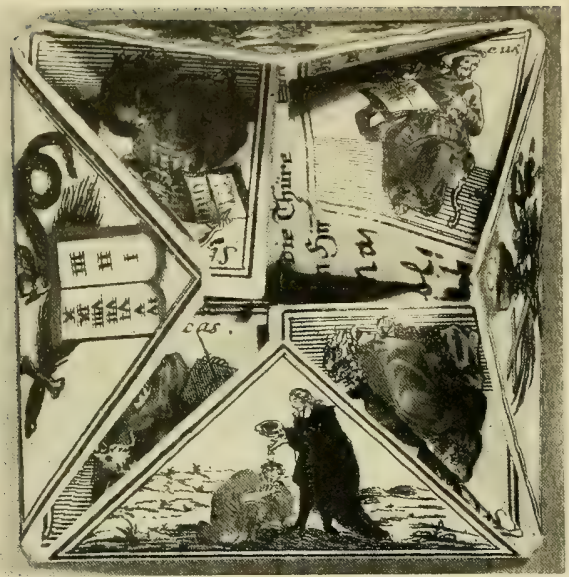

Cat. No. $17^{\circ}$

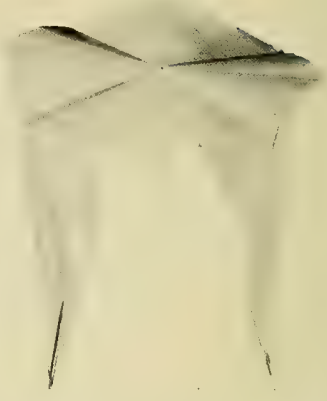

Cat. No. $7^{8}$

Cat. No. 65

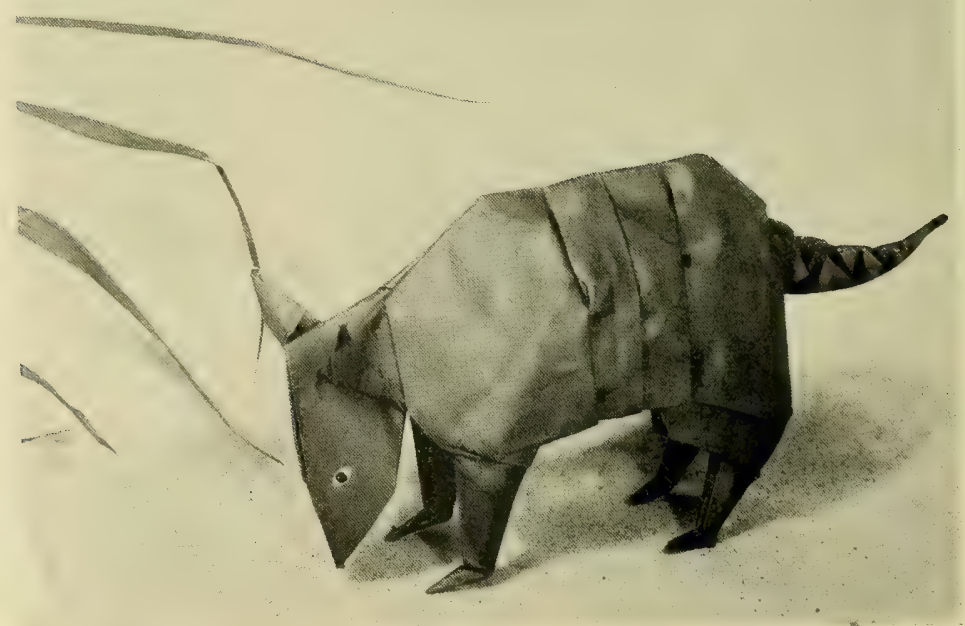


created in the western world that in quality rank with the best of the Japanese folds.

As diversion, paper folding is the province of some of the Occident's most creative minds. Shelley, and the author of Alice in Wonderland, Lewis Carroll, were eminent paper folders. Carroll mentions entertaining the royal children of the Duchess of Albany in his country home where he amused them by folding a fishing boat and, later, initiating "the little Duke of Albany ... in the art of making paper pistols." 17

The late Spanish philosopher, Miguel de Unamuno, is perhaps the best known among European and American folders, and the originality of his folds has been an inspirational guide to folders especially among the Spanish in Europe and South America. Like Lewis Carroli, Unamuno delighted in children, a delight typified in an account recorded by his friend, Eduardo Ortega y Gasset. Alone with Unamuno one day in the garden of his exile home in Hendaye was a little boy, Fernandito, who was enchanted with the animals and birds the famed philosopher had created from paper. "Fernandito contemplated . . . that zoological park when, suddenly, he turned to Don Miguel and said 'Don Miguel, do the little paper birds speak?' The master... was moved by the child's question. And the flash of inspiration illuminated that small world of paper." 18 So moved was Unamuno that he immediately went into the house and composed the lyrical poem that both opens and closes with the phrase

\section{"Speak! the child urges.}

\section{And it speaks!"}

Paper folding is an art on many levels: the compelling, moving experience it was for the philosopher, Unamuno; a pastime to fill, creatively, an idle hour; a sensitive art with overtones of the mystical experience fundamental to the practice of Zen; an art that probably served to illustrate Leonardo da Vinci's scientific essays; and an art immensely useful today in fields where the finished product relies on the precise understanding of the principles of physics and geometry.

The prosaically useful object, as well as the unique, rarefied work of art, satisfies our aesthetic senses when it is the result of creative forethought and imaginatively planned design. To view these several aspects of the art and technique of paper folding, as they are presented in exhibition, is to comprehend the artistic quality realizable in the simple act of folding a piece of paper.

EDWARD KaLLOP 


\section{NOTES}

${ }^{1}$ Hunter, Dard. Chinese Ceremonial Paper. Mountain House Press, Chillicothe, Ohio, 1937.

2 The Encyclopaedia Britannica. Fourteenth Edition, vol. 17, p. 229.

3 The skirts and sleeves of ancient Egyptian dress frequently had pleated folds as may be seen in any number of statues from the Middle Kingdom period, and an actual example, a pleated shirt from a Sixth Dynasty tomb at Naga-ed-Der, is illustrated in Riefstahl, Elizabeth. Patterned Textiles in Pharaonic Egypt, Brooklyn Museum, 1944, fig. 7 .

${ }^{4}$ Some idea of Byzantine imperial court dress is reflected in mosaics in Ravenna, and elsewhere, as well as described in such works as Ebersolt, J. Le grand palais de Constantinople et le liure des cérémonies, Paris, 1910.

${ }^{5}$ Illustrated very well in Holbein's paintings of contemporary ladies wearing stiffly folded headdresses. A variety of these are depicted in Wilcox, R. T. The Mode in Hats and Headdresses, New York, 1945, p. 97 fol.

- The society of St. Vincent de Paul was founded in France in the 17 th century, and the cap is an adaptation of the traditional Breton headdress for women.

7 Harssdörfer, George Philipp. Vollständiges Vermehrtes Trincir-Buch, Paulus Fürsten Kunsthändlern, Nuremberg, 1665 , p. 230-231. This rare book, a copy of which is owned by the Museum, illustrates a number of napkin folds typical of the period.

${ }^{8}$ Leonardo da Vinci. Il Codice Atlantico di Leonardo da Vinci nella Biblioteca Ambrosiana di Milano, Milan, 1894, vol. 4 , fig. $318 \mathrm{R}$ a. The text with the drawing speaks of "veloce," indicating a concern with speed and figures moving in space. Other illustrations of folded objects are figs. $231 \mathrm{R} \mathrm{c}, 240 \mathrm{~V} \mathrm{a}, 246 \mathrm{R} \mathrm{b}, 272 \mathrm{~V}$ a, and $273 \mathrm{~V} \mathrm{~b}$.
9 Beman and Smith. New Plane and Solid Geometry, p. 287. T. Sundara Row's Geometric Exercises in Paper Folding, edited and revised by Beman and Smith, Chicago, 1901, is completely devoted to the use of three-dimensional folding in geometry.

${ }^{10}$ Architectural Record, Sept. 1954, p. 176, shows a paper form illustrating an engineering principle that allows the apparently fragile paper to support a great weight superimposed. Typical paper fold forms realized in architectural use may be seen in Architectural Record, Nov. 1954, p. 223, fig. 17 and in Architectural Forum, April, 1954, p. 157.

${ }^{11}$ Moholy-Nagy, L. Vision in Motion, Chicago, 1946 , p. 81 .

${ }^{12}$ Anesaki, Masaharu. Art, Life and Nature in Japan, Boston, 1933, p. 104 fol.

${ }^{13}$ These terms are somewhat overlapping. The carefully tied knot may be called 'musubi' with the fold and knot together termed 'mizuhiki.' Generally speaking, however, Japanese shops sell simple folded paper forms as 'noshi' and the strings with which to tie the prescribed knot as 'mizuhiki.'

${ }^{14}$ Nagahiro Michide. Yoryu Origami Denjyu, circa 1719 .

15 Anesaki, op. cit. p. 53 fol.

16 ibid. p. 113

${ }^{17}$ Collingwood, S. D. The Life and Letters of Lewis Carroll, New York, 1899, p. 285 and p. 297.

18 Ortega y Gasset, Eduardo, Monodiálogos de Don Miguel de Unamuno, New York, 1958, p. $176 \mathrm{fol}$. Unamuno himself wrote a treatise on paper folding called Cocotologia o arte de hacer pajaritas de papel. 


\section{CATALOGUE}

Objects are lent by the maker unless followed by a number in parentheses, in which case refer to the list of contributors on last page.

\section{PAPER Folds}

Giuseppe Baggi; United States, New York

1. Three-Masted Schooner

2. Ship

3. Chinese Junk

4. Hawk

5. Stork

6. Giraffe

7. Kangaroo

8. Anteater

9. Bull

10. Rhinoceros

11. Running Man

12. Sitting Man

13. Strutting Man

14. Llama

15. Donkey

16. Elephant

17. Eagle

18. Eagle

19. Pair of Deer

20. Deer

21. Goose

22. Bird

23. Grotesque Bird

24. Penguin

25. Scorpion

26. Crab

27. Shrimp

28. Puzzle

29. Puzzle

3o. Wand

31. Cap

Martin Gardner; United States,

New York

32. Bat

Ernst Hacker; United States, New York

33. Ow1

34. Snake

35. Sheep

36. Mask

37. Pegasus
Ligia Montoya; Argentina, Buenos Aires

41. Group of Flowers

42. Fly

43. Two Moths

44. Three Beetles

45. Group of Birds

Robert Neale; United States, New York

46. Hawk

47. Dinosaurus

48. Cat

49. Dog

50. Bull and Matador

Robert Harbin; The West Indies, Jamaica

38. Angelfish

39. Crab

40. Polar Bear

Samuel L. Randlett; United States, Nashville

51. Dromedary Camel

52. Dromedary Camel

53. Resting Dromedary Camel

54. Two Butterflies

55. Gull

56. Five Gulls

57. Two Mice

58. Fish

59. Tortoise

6o. Sea Turtle

61. Pelican

62. Two Bats

63. Watch Dog

64. Egret

George Rhoads; United States, New York

65. Armadillo

66. Honking Goose

67. Two Beetles

68. Cardinal

69. Group of Bats

70. Dog

71. Dog

72. Beetle 
73. Giraffe

74. Three Elephants

75. Grasshopper

Jack Skillman; United States, Chicago

76. Rooster

77. Hobby Horse, in two pieces

Miguel De Unamuno (1864-1936); Spain
78. Table (11)
79. Crow (11)
8o. Teapot (11)
81. Elephant (11)
82. Frog (11)

Akira Yoshizawa; Japan, Tokyo

83. Crow (6)

84. Shark (6)

85. Cuttlefish (6)

86. Fur Seal (6)

87 . Giraffe (6)

88. Camel (6)

89. Doe (6)

90. Sparrows (6)

91. Ostrich (6)

92. $\operatorname{Dog}(6)$

93. Gorilla

94. Frog

95. Carp

96. Mask

97. Two Swans

98. Lion

99. Leaves

100. Eagle

101. Arrangement of Butterfly, Beetle and Leaves

102. Snail on Leaf

103. Two Foxes

104. Three Butterflies

105. Prawn (6)

106. Dove (6)

107. Vulture (6)

108. Two Turtles

109. March Hare (6)

110. Bat (6)

111. Squirrel (6)

112. Three Penguins (6)

113. Monkey (6)

114. Goose (6)

115. Macaw (6)

116. Three Flying Fish (6)

117. Badger (6)

118. Cock, Hen and Chicks (6)

119. Horse (6)

120. Three Mice (6)

121. Peacock

122. Sea Horse

123. Mantis (6)
124. Tortoise (6)

125. Fox

126. Emperor and Empress in Ceremonial Robes

\section{Traditional Folds}

127. Horse, European origin; George Rhoads; United States, New York

128. Two printer's caps, craft tradition; United States, New York (8)

129. Bird, Japanese origin; George Rhoads; United States, New York

130. Frog, Japanese origin; George Rhoads; United States, New York

131. Pagoda, Japanese origin; George Rhoads; United States, New York

132. Dragonfly, reconstructed from a diagram in the Kanomado Book of Origami, published in Japan, about $185^{\circ}$ (the original now lost); Ligia Montoya; Argentina, Buenos Aires

133. Crane, Japanese origin; Akira Yoshizawa; Japan, Tokyo (6)

134. Presentation box, Japanese origin; Akira Yoshizawa; Japan, Tokyo

135. Gift box, Japanese origin; Akira Yoshizawa; Japan, Tokyo

136. Box, Japanese origin; Japan (13)

137. Wedding gift set, Japanese origin; Japan (13)

\section{Essays in Three-Dimensional Form}

138. Class Exercise; Ellen Eisenberg; United States, New York (2)

139. Class Exercise; Shelagh Foreman; United States, New York (2)

140. Class Exercise; Shelagh Foreman; United States, New York (2)

141. Class Exercise; Joyce Hedman; United States, New York (2)

142. Class Exercise; Susan Kamen; United States, New York (2)

143. Class Exercise; Leanne Lipston; United States, New York (2)

144. Class Exercise; Esme Meyers; United States, New York (2)

145. Class Exercise; John Morris; United States, New York (2)

146. Fourteen Icicles; John Nordquist; United States, Pasadena

147. Class Exercise; Richard Piken; United States, New York (2)

148. Class Exercise; Robert Pilberg; United States, New York (2)

149. Geometric Form; George Rhoads; United States, New York

150. Geometric Form; George Rhoads; United States, New York 
151. Class Exercise; Ray Rich; United States, New York (2)

152. Class Exercise; Mary Sims; United States, New York (2)

153. Octahedron, Positive and Negative Pyramids; Jack J. Skillman; United States, Chicago

154. Octahedron, Negative volume; Jack J. Skillman; United States, Chicago

155. Trigonal Trisoctahedron; Jack J. Skillman; United States, Chicago

156. Class Exercise; Annette Weiss; United States, New York (2)

\section{Mathematical Exercises}

157. Four problems in enveloping conics: $\mathbf{H y -}$ perbola, Parabola, Ellipse, Tear Shaped Ellipse; Jack S. Berger; United States, New York (3)

158. Model explaining structural principles of a Hyperbolic Paraboloid, string, wire, wood; Stephen Furman; United States, New York (3)

159. Rhombicuboctahedron; Allan Sass; United States, New York (3)

16o. Trapezoidal Icositetrahedron; Allan Sass; United States, New York (3)

161. Pentakis Dodecahedron; Allan Sass; United States, New York (3)

162. Truncated Dodecahedron; Allan Sass; United States, New York (3)

Trade and Craft Applications

163. Two invitations for a film opening; Saul Bass; United States, Hollywood

164. Collar, embroidered silk; United States, about 1850 (4)

165. Skirt, black wool embroidered in colored wools; Burma, 19th century (4)

166. Skirt, black satin with pleats sewed in place; Peru, about 1860 (4)

167. Fan, brown satin, teak sticks; Spain, late 19th century (4)

168. Fan, painted gilt paper, bamboo sticks; Japan, early zoth century (4)

169. Fan, glazed brown muslin, tortoise-shell shaft; United States, late 19th century (4)

170. Baptism announcement, colored engraving; Johann Gottfried Böck (1741-1808) Germany, Augsburg, 1792 (4)

171. Baptism announcement, colored engraving; Johann Gottfried Böck (1741-1808) Germany, Augsburg, 1800 (4)

172. Trade card, "Ozone Soap," Lithograph; United States, about 1885 (4)

173. Plastic and wood desk lamp; Nori Sinoto; United States, New York (10)

174. Pattern for plastic desk lamp; Nori Sinoto; United States, New York
175. Two record cases; Nori Sinoto; United States, New York

176. Box for recording tape; Nori Sinoto; United States, New York

177. Rectangular box; Nori Sinoto; United States, New York

178. Two hat boxes; Nori Sinoto; United States, New York

179. Seven ash trays of various designs; Nori Sinoto; United States, New York

180. Box; Denmark, Copenhagen (12)

\section{Books}

181. Nagahiro Michide: Yoryu Origami Denjyu; Japan, about 1719 (13)

182. Ogasawara school book of model folds for gifts (noshi); Japan, early zoth century (13)

183. Ogasawara school book of model folds for gifts (noshi); Japan, early 2oth century (13)

184. Harssdörfer, George Philipp: Vollständiges Vermehrtes Trincir-Buch; Paulus Fürsten Kunsthändlern, Germany, Nuremberg, 1665 (4)

185. Tissandier, Gaston: Popular Scientific Recreations; Ward, Lock \& Bowden, Ltd., England, London, 1882 (5)

186. "Melange" scrap book, Ireland, 1820-1840 (4)

\section{Photographs}

187. Pleated linen dress, Egypt, about $125^{\circ}$ B.C.; Wooden statuette (7)

I 88. Folded cloth headdress, about 1435; Sculptured Head of Isabella of Bavaria (7)

189. Nun with sunshade; Brazil (7)

19o. Festive peasant dress; Spain, Aragón (7)

191. Paper model demonstrating structural strength achieved through folding ( 1 )

192. Exhibition booth at 1951 Hanover (Germany) Construction Fair (1)

193. Nun in folded headdress on the Harbor at San Juan; Photographer: Jack Delano (9)

194. Printers at work (8)

\section{DIAGRAMS}

195. Directions for folding a printer's cap; United States, New York (8)

196. Kanomado diagram for folding a dragonfly; published in Japan, about $185^{\circ}$ (reproduction)

197. Diagrams for folding an elephant; George Rhoads; United States, New York

198. Diagram for traditional folding of a pig; George Rhoads; United States, New York 


\section{CONTRIBUTORS}

1. Architectural Record

2. Cooper Union Art School

3. Cooper Union Engineering School

4. Cooper Union Museum

5. Martin Gardner

6. Gershon Legman

7. New York Public Library Picture Collection

8. The New York Times

9. Puerto Rico Office of Information

10. George Tanier, Inc.

11. Señorita Felisa de Unamuno

12. Mrs. William Vorhaus

13. Eugene Waddell 
$16 c^{5}$ 

